\title{
Litterfall and Nutrient Return in Eucalyptus dunnii Maiden in the Pampa Biome, Brazil
}

\author{
Dione Richer Momolli ${ }^{1}$, Mauro Valdir Schumacher ${ }^{1}$, Márcio Viera $^{1}$, Aline Aparecida Ludvichak ${ }^{1}$, \\ Claudiney do Couto Guimarães ${ }^{1} \&$ Huan Pablo de Souza ${ }^{1}$ \\ ${ }^{1}$ Department of Forest Sciences, Federal University of Santa Maria, Santa Maria, Rio Grande do Sul, Brazil \\ Correspondence: Dione Richer Momolli, Laboratório de Ecologia Florestal, Federal University of Santa Maria, \\ Santa Maria, RS, Brazil. Tel: 55-559-9727-1859. E-mail: dionemomolli@gmail.com
}

Received: January 3, 2019

Accepted: February 16, 2019 Online Published: April 15, 2019

doi:10.5539/jas.v11n5p362

URL: https://doi.org/10.5539/jas.v11n5p362

\begin{abstract}
The objective of this study was to evaluate litterfall and nutrient return in a Eucalyptus dunnii Maiden stand in the Pampa Biome. Four plots were established and four litter collectors per plot were distributed systematically with an area of $0.5 \mathrm{~m}^{2}$ and four subplots used to collect large branches of $>0.5 \mathrm{~cm}$ diameter. The collections were carried out biweekly with monthly chemical analyzes over 12 months. The annual litterfall was $8.48 \mathrm{Mg}$ $\mathrm{ha}^{-1}$, of which $59 \%$ was composed of leaves. In general, the leaves had the highest macronutrient contents except for $\mathrm{Mg}$. The total macronutrient return was $215 \mathrm{~kg} \mathrm{ha}^{-1}$, in the following order: $\mathrm{Ca}>\mathrm{N}>\mathrm{K}>\mathrm{Mg}>\mathrm{S}>\mathrm{P}$, with the leaves responsible for the return of $73 \%$ of the total. The litter represented an important source of organic matter and nutrients, and temperature is the climatic variable that best explains the pattern of production.
\end{abstract}

Keywords: nutrient cycling, nutritional sustainability, eucalyptus plantations

\section{Introduction}

Faced with the growth of population and their demand for products and forest by products, such as wood, cellulose, and energy, as well as the importance of forests in the regulation of the water cycle and carbon stock, companies in this sector and state development agencies see this as an opportunity to expand areas of tree cultivation.

According to IBÁ (2016), the area occupied by eucalyptus plantations in the Brazil increased from 3.4 million hectares in 2005 to 5.6 million hectares in 2015. This scale of growth was also observed in the State of Rio Grande do Sul (RS), with the area of eucalyptus plantations increasing from 179.7 thousand hectares in 2005 to 309.1 thousand hectares in 2015. Most of this increase occurred in the Pampa Biome, a region with little silvicultural tradition.

The soil of the Pampa Biome region is characterized by sandy texture and low natural fertility (IBGE, 2012). By understanding the dynamics of nutrient cycling, adequate forest management techniques can be determined, taking into account the rotation time and the input and output of nutrients (Gonçalves et al., 2005).

According to Suertegaray and Silva (2009), about 3.000 years ago, this region of the Pampa biome had a semi-arid and non-rainy climate, as it is today. The sand cores present today in the western state of RS occur naturally due to erosion, transport, and subsequent water and wind sedimentation. Grazing and other agricultural practices have intensified and accelerated this natural process.

Well known the production and decomposition of litter represents the main route of nutrient transfer to the soil, making it available again to the plants. Morphological characteristics, nutrient translocation capacity in different species, time of year, and management systems, determine the nutrient content (König et al., 2002). Among the different components of litter, leaves contribute the most mass and nutrient return to soil (Viera et al., 2014; Schumacher et al., 2013). Litterfall is influenced by several biotic and abiotic factors, such as temperature, light intensity, water and nutrients availability, population maturity, and population density (Viera et al., 2014).

Eucalyptus dunnii Maiden has been planted in the southern region mainly due to its ability to tolerate temperatures as cold as $-5^{\circ} \mathrm{C}$ and to resist damage caused by frost (Mora \& Garcia, 2000). Flores et al. (2016) classified this species has having high climatic suitability for the city of Alegrete-RS. 
The objective of the present study was to quantify the litterfall and nutrient return in an Eucalyptus dunnii stand established in low fertility natural soils.

\section{Method}

\subsection{Site Description}

The experiment was conducted in an area of forest production in the municipality of Alegrete-RS. According to Alvarez et al. (2014), the region has an average annual temperature of $18.6{ }^{\circ} \mathrm{C}$ and rainfall of $1500 \mathrm{~mm}$ distributed throughout the year.

Figure 1 shows a climatic diagram with the variables precipitation $(\mathrm{mm})$ and temperature $\left({ }^{\circ} \mathrm{C}\right)$ measured during the period, as well as the historical averages of ETP evapotranspiration in $(\mathrm{mm})$ according to AGRITEMPO (2018).

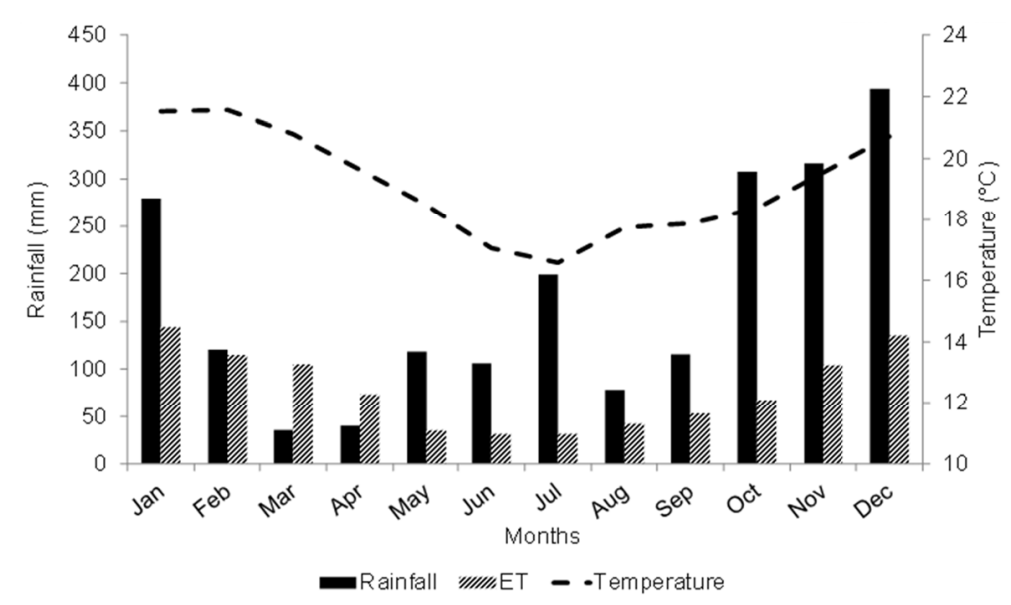

Figure 1. Climatic diagram with temperature $\left({ }^{\circ} \mathrm{C}\right)$, rainfall $(\mathrm{mm})$, and evapotranspiration $(\mathrm{mm})$, recorded in the area

The evaluations were carried out from January to December 2015. Planting was performed with spacing of $2.0 \times$ $3.5 \mathrm{~m}$. The initial control of ants occurred 45 days before the preparation of the soil with the application of granulated baits. Then herbicide was applied to total area, and subsoiling were performed at a depth of $50 \mathrm{~cm}$. Soon after planting, weeding was performed in the line and interweaving the planting, in addition to irrigation. Natural phosphate $\left(300 \mathrm{~kg} \mathrm{ha}^{-1}\right)$ was applied in the line during soil preparation. After 15 days of planting, $140 \mathrm{~kg}$ $\mathrm{ha}^{-1}$ of $\mathrm{N}-\mathrm{P}_{2} \mathrm{O}_{5}-\mathrm{K}_{2} \mathrm{O}$ formulation $06-30-06+0.3 \%$ of boron incorporated in the soil. At 40 and 90 days after planting, a further $120 \mathrm{~kg} \mathrm{ha}^{-1}$ of $\mathrm{N}-\mathrm{P}_{2} \mathrm{O}_{5}-\mathrm{K}_{2} \mathrm{O}$, formulation $22-01-18+0.3 \%$ boron $+0.2 \%$ copper was applied to the area.

Table 1 shows the chemical attributes of the soil when the stands reached 52-months old. According to the interpretation followed by Comissão de Química e Fertilidade do Solo CQFS (2004), the soil textural class was 4, indicating low clay content and M.O. The levels of $\mathrm{P}$ and $\mathrm{K}$ were very low; those of $\mathrm{Ca}$ and $\mathrm{Mg}$ low; and that of $\mathrm{S}$ was medium. Cation Exchange Capacity (pH 7.0) was average. 
Table 1. Soil chemical attributes in a Eucalyptus dunnii stand in Alegrete - RS

\begin{tabular}{|c|c|c|c|c|c|c|}
\hline \multirow{2}{*}{ Attribute } & \multirow{2}{*}{ Unit } & \multicolumn{5}{|c|}{ Depth $(\mathrm{cm})$} \\
\hline & & $0-20$ & $20-40$ & $40-60$ & $60-80$ & $80-100$ \\
\hline $\mathrm{MO}$ & \multirow{3}{*}{$\%$} & 0.9 & 1 & 1.1 & 1 & 1 \\
\hline V & & 7.7 & 7.1 & 14.9 & 20.9 & 21 \\
\hline $\mathrm{m}$ & & 81.6 & 81.3 & 68 & 55 & 55 \\
\hline $\mathrm{pH}$ & 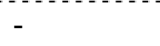 & 4.3 & 4.2 & 4.4 & 4.5 & 4.5 \\
\hline $\mathrm{Al}$ & \multirow{3}{*}{$\mathrm{cmol}_{\mathrm{c}} \mathrm{dm}^{-3}$} & 2.3 & 2.4 & 2.7 & 2.5 & 2.5 \\
\hline $\mathrm{Ca}$ & & 0.3 & 0,4 & 1,1 & 1,6 & 1,7 \\
\hline $\mathrm{Mg}$ & & 0.2 & 0.2 & 0.2 & 0,4 & 0.3 \\
\hline $\mathrm{P}$ & \multirow{2}{*}{$\mathrm{mg} \mathrm{dm}{ }^{-3}$} & 3 & 2.3 & 2.2 & 1.8 & 2.3 \\
\hline $\mathrm{K}$ & & 10.9 & 7.9 & 10.3 & 9.4 & 7.6 \\
\hline $\mathrm{t}$ & \multirow{2}{*}{$\mathrm{cmol}_{\mathrm{c}} \mathrm{dm}^{-3}$} & 2.8 & 3 & 4 & 4.5 & 4.5 \\
\hline $\mathrm{T}$ & & 6.7 & 7.7 & 8.5 & 9.7 & 9.7 \\
\hline
\end{tabular}

Note. $\mathrm{MO}=$ Organic matter; $\mathrm{P}$ and $\mathrm{K}=$ extraction with Mehlich-1 solution $(\mathrm{HCl}+\mathrm{H} 2 \mathrm{SO} 4) \mathrm{t}=$ Effective CTC $(\mathrm{Ca}+\mathrm{Mg}+\mathrm{K}+\mathrm{Al}) ; \mathrm{T}=\mathrm{CTC} \mathrm{pH} 7(\mathrm{Ca}+\mathrm{Mg}+\mathrm{K}+\mathrm{Al}+\mathrm{H}) ; \mathrm{V} \%=$ Base saturation; $\mathrm{m}=$ Aluminum saturation .

Source: Dick et al. (2016).

\subsection{Litterfall Collection and Chemical Analysis}

The experiment was performed in four plots $(20 \mathrm{~m} \times 21 \mathrm{~m})$, where four litter collectors per plot were installed in the following positions: line, row-spacing, diagonal. Collectors had an area of $0.5 \mathrm{~m}^{2}$. Thick branches $(>0.5 \mathrm{~cm}$ diameter) were collected by the demarcation of four useful areas of average trees $\left(7 \mathrm{~m}^{2}\right)$.

The collected material was transported to the laboratory in plastic bags, and then samples were separated into fractions containing leaves, twigs, thick branches, and miscellaneous (seed, immature fruits, and bark residues).

The fractions of litter in each trap were weighed and sub-samples were dried at $70{ }^{\circ} \mathrm{C}$ to a constant weight and then weighed to determine litterfall dry mass production. The mean annual litterfall per unit area $\left(\mathrm{Mg} \mathrm{ha}^{-1}\right)$ was calculated by summing the monthly litterfall values.

The chemical analyzes of plant tissue and soil followed the methodologies described by Miyazawa et al. (1999). For $\mathrm{N}$ analysis, sulfuric digestion $\left(\mathrm{H}_{2} \mathrm{SO}_{4}+\mathrm{H}_{2} \mathrm{O}_{2}\right)$ and Kjeldahl analysis were performed. The other elements $\mathrm{Ca}$, $\mathrm{Mg}, \mathrm{K}, \mathrm{P}$ and $\mathrm{S}$ passed through nitric-perchloric $\left(\mathrm{HNO}_{3}+\mathrm{HClO}_{4}\right)$ digestion, being atomic absorption spectrometry for $\mathrm{Ca}$ and $\mathrm{Mg}$, flame photometry for $\mathrm{K}$, spectrophotometry for $\mathrm{P}$ and turbidimetry for $\mathrm{S}$.

\subsection{Statistical Analysis}

Data analysis was performed using the SPSS software 20.0. It was considered the 4 installments as the repetition and the different seasons as treatments: summer (January, February and March), autumn (April, May and June), winter (July, August and September) and spring (October, November and December). After the statistically significant difference was verified, Tukey's test was applied at a 5\% probability of error.

In order to verify the influence of climatic variables on the pattern of litter deposition, Pearson's correlation was applied between the quantities of the different fractions and the climatic variables. The climatic data were obtained through the Alegrete-RS automatic station (AGRITEMPO, 2018), distant about $30 \mathrm{~km}$ from the experimental area.

The variation of macronutrient concentrations considered the seasons as independent variables (treatments). It was also verified the concentration variation in the different fractions of the litter. In both cases, Tukey's test was applied at a $5 \%$ probability of error.

\section{Results}

\subsection{Litterfall and Fractional Composition}

The total litterfall was $8.48 \mathrm{Mg} \mathrm{ha}^{-1}$, of which $59 \%$ corresponded to the leaves fraction, $19 \%$ thick branches, $11 \%$ miscellaneous, and $11 \%$ twigs (Table 2). 
Table 2. Litterfall in Eucalyptus dunnii in different fractions at 7 years of age

\begin{tabular}{llll}
\hline Fraction & $\mathrm{Mg} \mathrm{ha}^{-1}$ & $\mathbf{( \% )}$ & Monthly average $\left(\mathrm{kg} \mathrm{ha}^{-1}\right)$ \\
\hline Leaf & $5.17 \pm 0.232$ & 59.3 & 430.63 \\
Twig & $0.92 \pm 0.051$ & 11.12 & 76.72 \\
Thick branches & $1.46 \pm 0.078$ & 18.59 & 122.15 \\
Miscellaneous & $0.92 \pm 0.063$ & 11.02 & 76.92 \\
Total & 8.48 & 100 & 706.42 \\
\hline
\end{tabular}

Note. \pm Standard deviation in $\mathrm{Mg} \mathrm{ha}^{-1}$.

In Table 3, correlations between some climatic variables and litter deposition are presented. A significant correlation was observed for the variables maximum, minimum, mean temperates, potential evapotranspiration, solar radiation and maximum relative humidity.

Table 3. Pearson correlation between climatic variables and deposition of leaf, twig, thick branches, miscellaneous and total litterfall in Eucalyptus dunnii stands, 2015

\begin{tabular}{llllll}
\hline Variables & Litterfall & Leaves & Twigs & Thick branches & Miscellaneous \\
\hline Rainfall $(\mathrm{mm})$ & $\mathrm{ns}$ & $\mathrm{ns}$ & $\mathrm{ns}$ & $\mathrm{ns}$ & $\mathrm{ns}$ \\
Minimum temperature $\left({ }^{\circ} \mathrm{C}\right)$ & $0.80^{* *}$ & $0.82^{* *}$ & $\mathrm{~ns}$ & $\mathrm{~ns}$ & $\mathrm{~ns}$ \\
Mean temperature $\left({ }^{\circ} \mathrm{C}\right)$ & $0.79^{* *}$ & $0.82^{* *}$ & $\mathrm{~ns}$ & $\mathrm{~ns}$ & $\mathrm{~ns}$ \\
Maximum temperature $\left({ }^{\circ} \mathrm{C}\right)$ & $0.78^{* *}$ & $0.80^{* *}$ & $\mathrm{~ns}$ & $\mathrm{~ns}$ & $\mathrm{~ns}$ \\
Rainless $($ day) & $\mathrm{ns}$ & $\mathrm{ns}$ & $\mathrm{ns}$ & $\mathrm{ns}$ & $\mathrm{ns}$ \\
Minimum humidity $(\%)$ & $\mathrm{ns}$ & $\mathrm{ns}$ & $\mathrm{ns}$ & $\mathrm{ns}$ & $\mathrm{ns}$ \\
Maximum humidity $(\%)$ & $\mathrm{ns}$ & $\mathrm{ns}$ & $0.68^{*}$ & $\mathrm{~ns}$ & $\mathrm{~ns}$ \\
Evapotranspiration & $0.76^{* *}$ & $0.79^{* *}$ & $\mathrm{~ns}$ & $\mathrm{~ns}$ & $\mathrm{~ns}$ \\
Solar radiation & $0.65^{*}$ & $0.67^{*}$ & $\mathrm{~ns}$ & $\mathrm{~ns}$ & $\mathrm{~ns}$ \\
Wind $(\mathrm{m} / \mathrm{s})$ & $\mathrm{ns}$ & $\mathrm{ns}$ & $\mathrm{ns}$ & $\mathrm{ns}$ & $\mathrm{ns}$ \\
\hline
\end{tabular}

Note. Significant: * $(\mathrm{p} \leq 0.05) ; * *(\mathrm{p} \leq 0.01)$; ns: not significant.

Climatic variables are a source of AGRITEMPO (2018).

Over the months evaluated, the highest temperatures coincided with the months of highest deposition $(1,138 \mathrm{~kg}$ $\mathrm{ha}^{-1}$ ), while the lowest average temperature in July coincided with a deposition of only $158 \mathrm{~kg} \mathrm{ha}^{-1}$ (Figure 2).

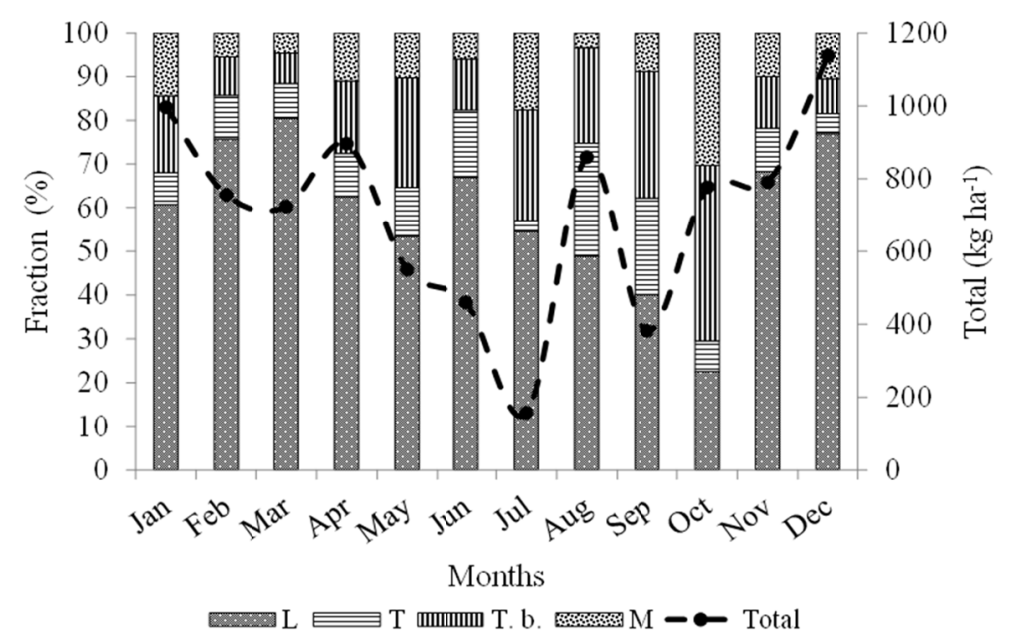

Figure 2. Monthly litterfall $\left(\mathrm{kg} \mathrm{ha}^{-1}\right)$ of the different fractions (\%); L: leaf; T: twig; T. b.: thick branches; M: miscellaneous, and total, in Eucalyptus dunnii at 7 years of age 


\subsection{Nutrient Content in Litterfall Fractions}

The leaf litter presented the highest mean concentration of all macronutrients, except for Mg. P contents were found in descending order in the following fractions leaves $>$ miscellaneous $>$ twig $>$ thick branches, as shown in Figure 3.
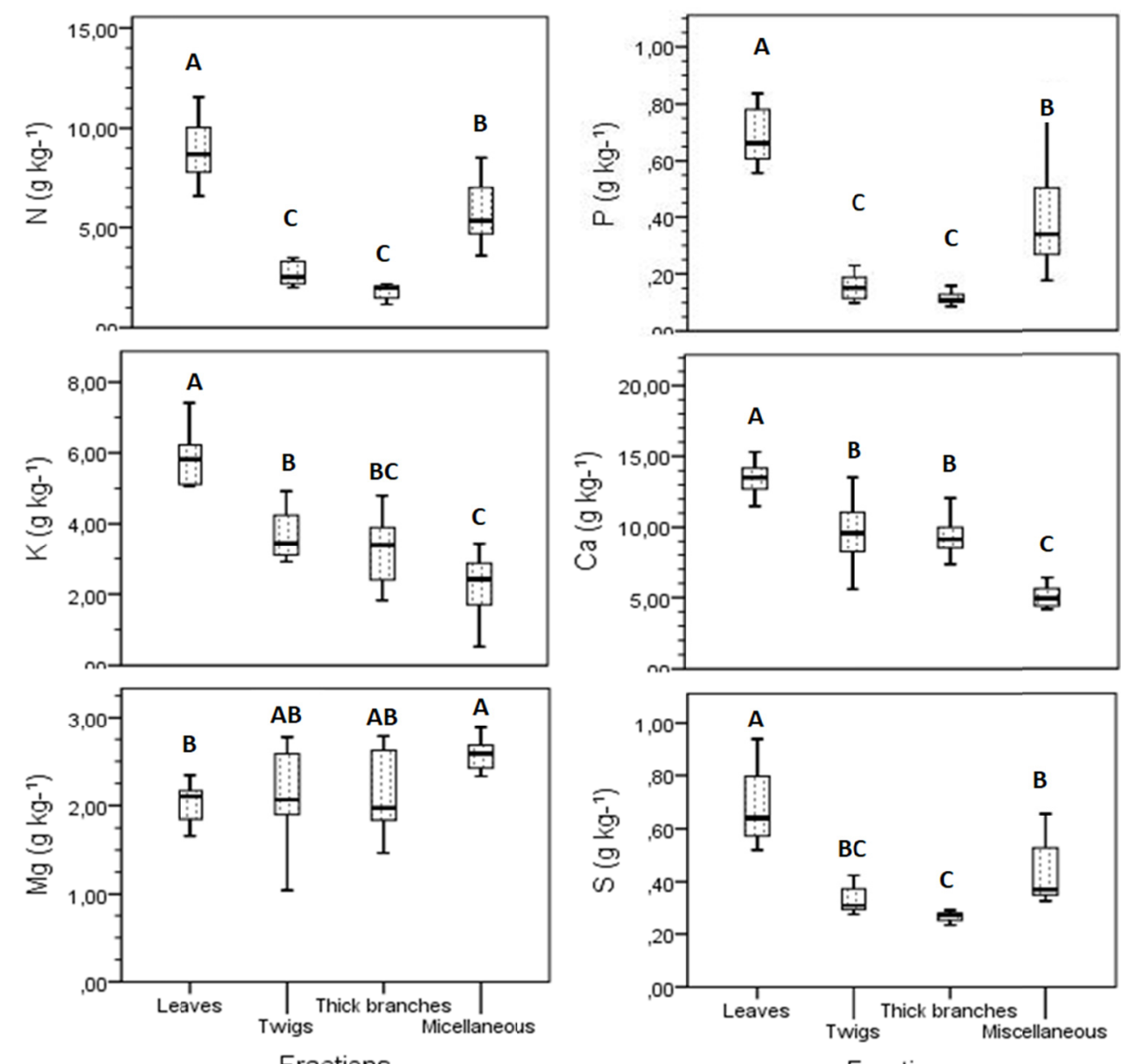

Figure 3. Average concentration of macronutrients in the different fractions of Eucalyptus dunnii litterfall

Note. The values in the horizontal followed by the same letter do not differ significantly by Tukey's test at $5 \%$ error.

In the present study, the leaf fraction had an average $\mathrm{P}$ content of $0.69 \mathrm{~g} \mathrm{~kg}^{-1}$. In relation to the concentration of nutrients in the leaves, it was observed that in general the spring presented the highest means except for calcium (Table 4). 
Table 4. Average concentration of macronutrients in the different fractions of litterfall and annual seasons from Eucalyptus dunnii

\begin{tabular}{|c|c|c|c|c|c|c|}
\hline Season & $\mathbf{N}$ & $\mathbf{P}$ & $\mathbf{K}$ & $\mathbf{C a}$ & Mg & $\mathbf{S}$ \\
\hline & -----------. & ----------- & --------- & $\mathrm{g}^{-1}--\cdot-\cdot-\cdot$ & -------------- & -------------- \\
\hline \multicolumn{7}{|l|}{ Leaves } \\
\hline Summer & $7.70 \mathrm{~B}$ & $0.58 \mathrm{~B}$ & $4.83 \mathrm{~A}$ & $13.20 \mathrm{AB}$ & $1.86 \mathrm{~B}$ & $0.60 \mathrm{~B}$ \\
\hline Autumn & $7.39 \mathrm{~B}$ & $0.65 \mathrm{AB}$ & $5.57 \mathrm{~A}$ & $14.56 \mathrm{~A}$ & $2.05 \mathrm{AB}$ & $0.56 \mathrm{~B}$ \\
\hline Winter & $9.70 \mathrm{AB}$ & $0.78 \mathrm{~A}$ & $6.27 \mathrm{~A}$ & $13.77 \mathrm{~A}$ & $2.00 \mathrm{AB}$ & $0.81 \mathrm{~A}$ \\
\hline Spring & $11.30 \mathrm{~A}$ & $0.73 \mathrm{~A}$ & $5.00 \mathrm{~A}$ & $12.30 \mathrm{~B}$ & $2.26 \mathrm{~A}$ & $0.79 \mathrm{~A}$ \\
\hline Average & $9.02+2.02$ & $0.68+0.09$ & $5.42+1.38$ & $13.46+0.06$ & $2.04+0.21$ & $0.69+0.14$ \\
\hline \multicolumn{7}{|l|}{ Twigs } \\
\hline Summer & $2.47 \mathrm{~A}$ & $0.14 \mathrm{~A}$ & $3.07 \mathrm{~A}$ & $9.24 \mathrm{~A}$ & $1.92 \mathrm{~A}$ & $0.30 \mathrm{~A}$ \\
\hline Autumn & $2.27 \mathrm{~A}$ & $0.13 \mathrm{~A}$ & $4.04 \mathrm{~A}$ & $9.98 \mathrm{~A}$ & $2.17 \mathrm{~A}$ & $0.29 \mathrm{~A}$ \\
\hline Winter & $2.78 \mathrm{~A}$ & $0.15 \mathrm{~A}$ & $4.04 \mathrm{~A}$ & $10.71 \mathrm{~A}$ & $2.18 \mathrm{~A}$ & $0.34 \mathrm{~A}$ \\
\hline Spring & $3.35 \mathrm{~A}$ & $0.23 \mathrm{~A}$ & $3.50 \mathrm{~A}$ & $8.73 \mathrm{~A}$ & $2.30 \mathrm{~A}$ & $0.38 \mathrm{~A}$ \\
\hline Average & $2.73+0.57$ & $0.16+0.06$ & $3.66+0.68$ & $9.66+2.31$ & $2.14+0.51$ & $0.33+0.05$ \\
\hline \multicolumn{7}{|c|}{ Thick branches } \\
\hline Summer & $1.90 \mathrm{~A}$ & $0.12 \mathrm{~A}$ & $2.34 \mathrm{~A}$ & $8.71 \mathrm{~A}$ & $2.02 \mathrm{~A}$ & $0.26 \mathrm{~A}$ \\
\hline Autumn & $1.63 \mathrm{~A}$ & $0.10 \mathrm{~A}$ & $3.57 \mathrm{~A}$ & $9.93 \mathrm{~A}$ & $2.02 \mathrm{~A}$ & $0.27 \mathrm{~A}$ \\
\hline Winter & $1.95 \mathrm{~A}$ & $0.12 \mathrm{~A}$ & $3.11 \mathrm{~A}$ & $9.52 \mathrm{~A}$ & $2.42 \mathrm{~A}$ & $0.25 \mathrm{~A}$ \\
\hline Spring & $2.08 \mathrm{~A}$ & $0.13 \mathrm{~A}$ & $4.11 \mathrm{~A}$ & $9.10 \mathrm{~A}$ & $2.10 \mathrm{~A}$ & $0.30 \mathrm{~A}$ \\
\hline Average & $1.89+0.50$ & $0.12+0.02$ & $3.28+1.00$ & $9.31+1.27$ & $2.14+0.46$ & $0.27+0.03$ \\
\hline \multicolumn{7}{|c|}{ Miscellaneous } \\
\hline Summer & $4.32 \mathrm{~B}$ & $0.24 \mathrm{~A}$ & $1.57 \mathrm{~A}$ & $4.36 \mathrm{~A}$ & $2.65 \mathrm{~A}$ & $0.35 \mathrm{~B}$ \\
\hline Autumn & 4.69 B & $0.28 \mathrm{~A}$ & $2.67 \mathrm{~A}$ & $5.41 \mathrm{~A}$ & $2.55 \mathrm{~A}$ & $0.34 \mathrm{~B}$ \\
\hline Winter & $6.86 \mathrm{AB}$ & $0.57 \mathrm{~A}$ & $2.58 \mathrm{~A}$ & $6.33 \mathrm{~A}$ & $2.19 \mathrm{~A}$ & $0.58 \mathrm{~A}$ \\
\hline Spring & $7.49 \mathrm{~A}$ & $0.49 \mathrm{~A}$ & $2.19 \mathrm{~A}$ & $5.05 \mathrm{~A}$ & $2.66 \mathrm{~A}$ & $0.47 \mathrm{AB}$ \\
\hline Average & $5.84+1.66$ & $0.39+0.18$ & $2.25+0.84$ & $5.29+1.18$ & $2.51+0.31$ & $0.43+0.11$ \\
\hline
\end{tabular}

Macronutrients were mainly provided by the leaf fraction (73\%), followed by thick branches (12\%), twigs (9\%), and miscellaneous (7\%) fractions (Table 5). The total quantity returned to the forest floor was $215.22 \mathrm{~kg} \mathrm{ha}^{-1}$, in which the following order of macronutrient deposition was found: $\mathrm{Ca}>\mathrm{N}>\mathrm{K}>\mathrm{Mg}>\mathrm{S}>\mathrm{P}$.

Table 5. Annual contribution of macronutrients to litterfall fractions in a 7-year-old Eucalyptus dunnii stand

\begin{tabular}{|c|c|c|c|c|c|c|c|}
\hline Fraction & $\mathrm{N}$ & $\mathrm{P}$ & $\mathrm{K}$ & $\mathrm{Ca}$ & $\mathrm{Mg}$ & $\mathrm{S}$ & Total \\
\hline & ----------- & ------- & --------- & $\mathrm{ha}^{-1}-\cdots$ & ----- & -------- & \\
\hline \multirow[t]{2}{*}{ Leaf } & 45.22 & 3.4 & 26.1 & 67.77 & 10.59 & 3.56 & 156.65 \\
\hline & $(21.01)^{*}$ & $(1.58)$ & (12.13) & (31.49) & $(4.92)$ & $(1.65)$ & (72.79) \\
\hline \multirow[t]{2}{*}{ Twig } & 2.46 & 0.15 & 3.56 & 9.81 & 2.09 & 0.3 & 18.36 \\
\hline & (1.14) & $(0.07)$ & $(1.65)$ & $(4.56)$ & $(0.97)$ & $(0.14)$ & $(8.53)$ \\
\hline \multirow[t]{2}{*}{ Thick branches } & 2.77 & 0.16 & 4.66 & 14.4 & 3.07 & 0.38 & 25.44 \\
\hline & $(1.29)$ & $(0.08)$ & $(2.16)$ & $(6.69)$ & (1.43) & $(0.18)$ & $(11.82)$ \\
\hline \multirow[t]{2}{*}{ Miscellaneous } & 5.08 & 0.33 & 1.73 & 4.71 & 2.54 & 0.37 & 14.77 \\
\hline & $(2.36)$ & $(0.16)$ & $(0.81)$ & $(2.19)$ & (1.18) & $(0.17)$ & $(6.86)$ \\
\hline \multirow[t]{2}{*}{ Total } & 55.52 & 4.05 & 36.05 & 96.69 & 18.29 & 4.61 & 215.22 \\
\hline & $(25.8)$ & $(1.88)$ & $(16.75)$ & (44.93) & $(8.5)$ & $(2.14)$ & $(100)$ \\
\hline
\end{tabular}

Note. ${ }^{*}$ Values in parentheses refer to the percentage of macronutrients in each litterfall compartment.

\section{Discussion}

\subsection{Litterfall and Fractional Composition}

Schumacher et al. (2013) studied the Eucalyptus urophylla $\times$ Eucalyptus globulus maidenii hybrid and found a litterfall average of $7.44 \mathrm{Mg} \mathrm{ha}^{-1}$ at 7-8 years old in Eldorado do Sul-RS. Similar to the present study, $60 \%$ of the litter consisted of the leaves fraction, $16 \%$ of twigs, $13 \%$ of thick branches, and $10 \%$ miscellaneous. 
Evaluating the pattern of litter deposition in forest ecosystems distributed in 257 sites worldwide, Zhang et al. (2014) show that the percentage of leaves varied from 64 to $73 \%$. This trend has been confirmed in other studies, which have reported that the leaves contribute the greatest amount to the litter. Viera et al. (2014) also evaluated the average annual deposition of litter from years 6 to 9 in Eucalyptus urophylla $\times$ E. globulus hybrid and found a total of $7.54 \mathrm{Mg} \mathrm{ha}^{-1}$, consisting of $67 \%$ leaves, $15 \%$ twigs, $10 \%$ miscellaneous, and $8 \%$ thick branches, with the intrinsic variation due to maturity, to the species and to the place where the stand is established.

In a 2-year-old stand of Eucalyptus dunnii established in sandy soil, Corrêa et al. (2013) reported the production of $4.1 \mathrm{Mg} \mathrm{ha}^{-1}$ litter. Of this, the leaves represented about $93 \%$ of the total and the thick branches only $1 \%$. For the present study, the contribution of the total branch fraction was $29.7 \%$. The explanation is given by the fact that when trees grow, increases the closure of the canopy and the leaves and branches in the lower thirds are shaded, reducing the photosynthetic rate and increasing the deposition of branches with larger diameters.

Evaluating litter production in three successional stages (young, medium, and second growth) in addition to old growth, Aryal et al. (2015) show that the percentage of leaves decreased as the stands aged, from $91 \%$ at year 5 to $84 \%$ in primary forest. The inverse was observed for branches, which increased from 5 to $10 \%$ for the same forest formations. Gonçalves et al. (2005) stated that increased competition for growth factors, such as light and physical space, accounts for the increased number of thick branches.

As with Viera et al. (2014), the average, minimum and maximum air temperature, evapotranspiration and solar radiation variables influenced significantly $(\mathrm{p} \leq 0.01$ and 0.05$)$ in total and leaf litter deposition. The climatic temperature variable was the one that best explained the deposition of litter, with average correlations of $80 \%$. However, the same behavior cannot be observed with the precipitation in the present study, possibly due to the volume of rainfall being more constant during the year, without significant reduction or water deficit during the evaluation.

For Viera and Schumacher (2010a, 2010b), during periods of lower rainfall, there is a greater deposition of litter especially of leaves. This occurs as a strategy of the plant avoiding excessive losses due to evapotranspiration during these more critical periods (Martins \& Rodrigues, 1999). Zhang et al. (2014) reported that precipitation and solar radiation were limiting factors affecting the regulation of litter in tropical forests.

According Viera et al. (2014), increased temperature can accelerate the rate of transpiration and consequently, the increased level of salts in the leaves. This results in the greater senescence of mature leaves.

Antoneli and Francisquini (2014), evaluated the correlation between litter production and meteorological data in Mixed Ombrophylous Forest belonging to a Federal Conservation Unit located in the municipality of Irati-PR and concluded that the climate exerts a late influence on litter deposition. Minimum temperatures resulted in a low monthly correlation and high seasonal correlation.

However, it has also been reported that peak deposition in autumn or winter is mainly caused by falling temperatures, by a period marked by water stress (Nadkara, 2011), or by coinciding with leaf fall due to the emission of new leaves following the period of most abundant radiation (Zelamea \& González, 2008).

In the Caatinga Biome of the semi-arid region, Santana and Souto (2011) found values much lower at $2.06 \mathrm{Mg}$ $\mathrm{ha}^{-1}$. Those authors reported that the Caatinga vegetation is strongly influenced by climatic conditions, especially precipitation, which seems to trigger the senescence process. As a physiological strategy, this adapted vegetation reduces its leaf surface, thus reducing the loss of water by the system.

\subsection{Nutrient Content in Litterfall Fractions}

For Viera et al. (2010) the highest concentration observed in the leaf fraction was the result of the most active cellular activity in those tissues. Ludvichak et al. (2016) studied 5-year-old Eucalyptus dunnii stands and observed that the leaf fraction differed significantly in the concentration of all nutrients compared with the other fractions.

Lima et al. (2010) studied the average levels of accumulated leaf litter in different systems, including: agroforestry, ecological, cutting agriculture, and native forest, and found average levels much higher than nitrogen, highlighting mainly agroforestry for 6 and 10 years with concentrations of 19.2 and $22.2 \mathrm{~g} \mathrm{~kg}^{-1}$, respectively, during the rainy season and 13.7 and $18.2 \mathrm{~g} \mathrm{~kg}^{-1}$, respectively, during the dry season. Compared with the value of $9.02 \mathrm{~g} \mathrm{~kg}^{-1}$ observed in the present study, the highest levels of this element reported by those authors was due to the association of agricultural species, including legumes with forest species. Another factor that may account for the considerable increase in these contents is biological fixation promoted by the most diversified biota. 
Phosphorus $(\mathrm{P})$ is an element subjected to high levels of internal translocation in plants and is associated with high metabolic activity, mainly in the younger tissues as well as in the leaves. Lima et al. (2010), found markedly higher levels in an agroforestry system at 10 years, with 3.0 and $6.2 \mathrm{~g} \mathrm{~kg}^{-1}$ observed for the same fraction in the rainy and dry seasons, respectively.

The mean concentration of $\mathrm{Ca}$ was the highest among evaluated nutrients. In this way, crystals are formed within the cell, which remain in the tissue even during senescence (König et al., 2002).

Spring is the season of resumption of physiological activity, preceded by the winter which is characterized by a greater resting of the metabolism of the plant. In this way, the elements of greater mobility are translocated to the leaves as is the case of $\mathrm{N}$ and $\mathrm{P}$. The inverse behavior is observed for the $\mathrm{Ca}$, since it has low mobility, being thus observed its highest concentrations in the autumn and winter.

\subsection{Nutrient Return to the Forest Floor}

Other studies have reported the same order, including Corrêa et al. (2013) for Eucalyptus dunnii, and Viera et al. (2014) for Eucalyptus urophylla $\times$ Eucalyptus globulus hybrid. Gonzalez-Rodriguez et al. (2011) assessed the contribution of nutrients through leaf litter in four different sites in northeastern Mexico and found the same order: $\mathrm{Ca}>\mathrm{N}>\mathrm{K}>\mathrm{Mg}>\mathrm{P}$.

However, compared with the results of a study performed by Freitas et al. (2013) in an agro-silvopastoral eucalyptus-acacia system, the following order was observed: $\mathrm{N}>\mathrm{Ca}>\mathrm{K}>\mathrm{Mg}>\mathrm{S}>\mathrm{P}$, where $\mathrm{N}$ represented $52 \%$ of the total macronutrients returned to soil. In our study, $\mathrm{N}$ represented about $26 \%$ of the total. This difference is due to the fact that acacia is a leguminous species with potential for biological nitrogen fixation.

Due to their predominance in biomass, the leaves contribute to the highest intake of macronutrients (Viera et al., 2014). Due to the high $\mathrm{Ca}$ concentrations in plant tissue, this element contributed the most to the quantity supplied to the forest floor (44.9\%). Viera et al. (2014) found similar values (40\%). Corrêa et al. (2013) studied Eucalyptus dunnii at 2 years of age and found $46.6 \% \mathrm{Ca}$.

\section{Conclusions}

The climatic variables temperature, solar radiation and evapotranspiration have a strong influence on the pattern of litterfall, showing that it has a seasonal character. In general, the leaves had the highest macronutrient contents except for Mg.

The amount of annual litterfall is an important source of organic matter and nutrients for the soil, improving the chemical attributes and protecting the superficial layers against erosive processes in these areas of the Pampa Biome. Leaf fraction was the most representative in terms of amount of biomass and contribution of nutrients to the soil.

Considering the release rate of the leaf litter macronutrients in the same Eucalyptus dunnii stands (Momolli et al., 2018), the stocks after 3 years of deposition will be $32.96 \mathrm{~kg} \mathrm{ha}^{-1}$. This represents $21 \%$ of the leaf nutrients remaining and serving as a source of slow release at future rotations.

\section{Acknowledgements}

The first author thanks the Coordination for the Improvement of Higher Education Personnel (CAPES) for the scholarship.

\section{References}

AGRITEMPO. (2018). Dados meteorológicos-Alegrete. Retrieved from http://www.agritempo.gov.br

Alvares, C. A., Stape, J. L., Sentelhas, P. C., Gonçalves, J. L. M., \& Sparovek, G. (2014). Köppen's climate classification map for Brazil. Meteorologische Zeitschrift, 22(6), 711-728. https://doi.org/10.1127/09412948/2013/0507

Antoneli, V., \& Francisquini, V. M. (2014). Influência de alguns dados meteorológicos na produção de serapilheira na flona (Floresta Nacional) de Irati-PR. Ambiência, 10(1), 267-280.

Aryal, D. R., Jong, B. H. J., Ochoa-Gaona, S., Mendoza-Veja, J., \& Esparza-Olguin, L. (2015). Successional and seasonal variation in litterfall and associated nutriente transfer in semi-evergreen tropical forests of SE Mexico. Nutr. Cycl. Agroecosyst, 103(1), 45-60. https://doi.org/10.1007/s10705-015-9719-0

Corrêa, R. S., Schumacher, M. V., \& Momolli, D. R. (2013). Deposição de serapilheira e macronutrientes em povoamento de Eucalyptus dunnii maiden sobre pastagem natural degradada no bioma pampa. Scientia Forestalis, 41(97), 65-74. 
CQFS (Comissão de Química e Fertilidade do Solo). (2004). Manual de adubação e de calagem para os estados do Rio Grande do Sul e de Santa Catarina (p. 400).

Dick, G., Schumacher, M. V., \& Momolli, D. R. (2016). Caracterização da fertilidade do solo em um povoamento de Eucalyptus dunnii Maiden no bioma Pampa do Rio Grande do Sul. Ecologia e Nutrição Florestal, 4(3), 68-77. https://doi.org/10.5902/2316980X20588

Ferreira, R. L. C., Junior, M. A. L., Rocha, M. S., Santos, M. V. F., Lira, M. A., \& Barreto, L. P. (2007). Deposição e acúmulo de matéria seca e nutrientes em serapilheira em um bosque de sabiá (Mimosa caesalpiniifolia benth.). Revista Árvore, 31(1), 7-12. https://doi.org/10.1590/S0100-67622007000100002

Flores, T. B., Alvares, C. A., Souza, V. C., \& Stape, J. L. (2016). Eucalyptus no Brasil: Zoneamento climático e guia para identificação. Piracicaba: IPEF.

Freitas, E. C. S., Neto, S. N. O., Fonseca, D. M., Santos, M. V., Leite, H. G., \& Machado, V. D. (2013). Deposição de serapilheira e de nutrientes no solo em sistema agrossilvipastoril com eucalipto e acácia. Revista Árvore, 37(3), 409-417. https://doi.org/10.1590/S0100-67622013000300004

Gonçalves, J. L. M., Stape, J. L., Benedetti, V., Fessel, V. A. G., \& Gava, J. L. (2005). Reflexos do cultivo mínimo e intensivo do solo em sua fertilidade e na nutrição das árvores. In J. L. M. Gonçalves, \& V. Benedetti (Eds.), Nutrição e fertilização florestal (pp. 1-57).

González-Rodrígues, H., Domínguez-Gómez, T. G., Cantú-Silva, I., Gómez-Meza, M. V., Ramírez-Lozano, R. G., \& Pando-Moreno, M., (2011). Litterfall deposition and leaf litter nutrient return in different locations at northeastern Mexico. Plant Ecol., 212, 1747-1757. https://doi.org/10.1007/s11258-011-9952-9

IBÁ (Indústria Brasileira de Árvores). (2016). Relatório anual 2016: Ano base 2015 (p. 80).

IBGE (Instituto Brasileiro de Geografia e Estatística). (2012). Manual Técnico da Vegetação Brasileira (p. 271).

IBM Corp. (2011). IBM SPSS Statistics for Windows, Version 20.0. Armonk, NY: IBM Corp.

König, F. G., Schumacher, M. V., Brun, E. J., \& Seling, I. (2002). Avaliação da sazonalidade da produção de serapilheira numa Floresta Estacional decidual no município de Santa Maria-RS. Revista Árvore, 26(4), 429-435. https://doi.org/10.1590/S0100-67622002000400005

Lima, S. S., Leite, L. F. C., Aquino, A. M., Oliveira, F. C., \& Castro, A. A. J. F. (2010). Serapilheira e teores de nutrientes em argissolo sob diferentes manejos no norte do Piauí. Revista Árvore, 34, 75-84. https://doi.org/10.1590/S0100-67622010000100009

Ludvichack, A. P., Schumacher, M. V., Dick, G., Momolli, D. R., Souza, H. P., \& Guimarães, C. C. (2016). Devolução de nutrientes através da serapilheira produzida em um povoamento de Eucalyptus dunnii maiden em solo arenoso. Revista Árvore, 40(6), 1041-1048.

Martins, S. V., \& Rodrigues, R. R. (1999). Produção de serapilheira em clareiras de uma floresta estacional semidecidual no município de Campinas, SP. Revista Brasileira de Botânica, 22(3), 405-412. https://doi.org/10.1590/S0100-84041999000300009

Miyazawa, M., Pavan, M. A., \& Muraoka, T. (1999). Manual de análises químicas de solos, plantas e fertilizantes. Brasília: Embrapa Comunicação Para Transferência de Tecnologia.

Momolli, D. R., Schumacher, M. V., Dick, G., Viera, M., \& Souza, H. P. (2018). Decomposição da serapilheira foliar e liberação de nutrientes em Eucalyptus dunnii no Bioma Pampa. Scientia Forestalis, 46(118), 199-208. https://doi.org/10.18671/scifor.v46n118.06

Mora, A. L., \& Garcia, C. H. (2000). A cultura do eucalipto no brasil (p. 112). São Paulo: SBS.

Nadkara, O. E. (2011). Litterfall and nutrient returns in isolated stands of Persea gratissima (avocado pear) in the rainforest zone of southern Nigeria. Ethiop. J. of Environ. Stud. and Manage, 4(3). https://doi.org/10.4314/ ejesm.v4i3.6

Santana, J. A. S., \& Souto, J. S. (2011). Produção de serapilheira na caatinga da região semi-árida do Rio Grande do Norte, Brasil. Idesia, 29, 87-94. https://doi.org/10.4067/S0718-34292011000200011

Schumacher, M. V., Brun, E. J., Rodrigues, L. M., \& Santos, E. M. (2003). Retorno de nutrientes via deposição de serapilheira em um povoamento de acácia-negra (Acacia mearnsii de wild.) no estado do Rio Grande do Sul. Revista Árvore, 27, 791-798. https://doi.org/10.1590/S0100-67622003000600005 
Schumacher, M. V., Corrêa, R. S., Viera, M., \& Araújo, E. F. (2013). Produção e decomposição de serapilheira em um povoamento de Eucalyptus urophylla $\times$ Eucalyptus globulus maidenii. Cerne, 19(3), 501-508. https://doi.org/10.1590/S0104-77602013000300018

Suertegaray, D. M. A., \& Silva, L. A. P. (2009). Tchê Pampa: histórias da natureza gaúcha. In V. P. Pilar et al. (Eds.), Campos sulinos: Conservação e uso sustentável da biodiversidade (pp. 42-49). Brasília: MMA.

Viera, M., \& Schumacher, M. V. (2010a). Deposição de serapilheira e de macronutrientes em um povoamento de acácia negra (Acacia mearnsii De Wild.) no Rio Grande do Sul. Ciência Florestal, 20(2), 225-233. https://doi.org/10.5902/198050981848

Viera, M., \& Schumacher, M. V. (2010b). Variação mensal da deposição de serapilheira em povoamento de Pinus taeda L. em área de campo nativo em Cambara do Sul-RS. Revista Árvore, 34(3), 487-494. https://doi.org/10.1590/S0100-67622010000300012

Viera, M., Caldato, S. L., Rosa, S. F., Kanieski, M. R., Araldi, D. B., Santos, S. R., \& Schumacher, M. V. (2010). Nutrientes na serapilheira em um fragmento de floresta estacional decidual, Itaara, RS. Ciência Florestal, 20(4), 611-619. https://doi.org/10.5902/198050982419

Viera, M., Schumacher, M. V., Araújo, E. F., Corrêa, R. S., \& Caldeira, M. V. W. (2014). Deposição de serapilheira e nutrientes em plantio de Eucalyptus urophylla $\times$ Eucalyptus globulus. Floresta Ambiente, 21(3), 327-338. https://doi.org/10.1590/2179-8087.053913

Zelamea, M., \& González, G. (2008). Leaffall phenology in a subtropical wet forest in Puerto Rico: From species to community patterns. Biotropica, 40, 295-304. https://doi.org/10.1111/j.1744-7429.2007.00389.x

Zhang, H., Yuan, W., Dong, W., \& Liu, S. (2014). Seasonal patterns of litterfall in forest ecosystem worldwide. Ecological Complexity, 20, 240-247. https://doi.org/10.1016/j.ecocom.2014.01.003

\section{Copyrights}

Copyright for this article is retained by the author(s), with first publication rights granted to the journal.

This is an open-access article distributed under the terms and conditions of the Creative Commons Attribution license (http://creativecommons.org/licenses/by/4.0/). 